\title{
Other Legal Workers
}

National Cancer Institute

\section{Source}

National Cancer Institute. Other Legal Workers. NCI Thesaurus. Code C122547.

Legal workers not specifically identified elsewhere. 